\title{
Comparative Evaluation of the Rheological Properties, upon Addition of Water, of Three Commercially Available Zinc Oxide Eugenol Impression Materials
}

\author{
Savitha Dandekeri ${ }^{1}$, Rochelle D'Souza², Uma Mayoor Prabhu³, \\ Sanath Kumar Shetty ${ }^{4}$, Karkala Sayed Suhaim ${ }^{5}$, Fowzaan Feroz ${ }^{6}$
}

1, 2, 3, 4, 5, 6 Department of Prosthodontics, Yenepoya Dental College, Yenepoya University, Mangalore, Karnataka, India.

\section{ABSTRACT}

\section{BACKGROUND}

Zinc oxide eugenol (ZOE) impression paste is commonly used for secondary impression. Water acts as an accelerator to zinc oxide eugenol paste. Study was carried out to determine its flow property and the effect of addition of water on flow properties for different commercially available zinc oxide eugenol impression pastes. We wanted to compare and evaluate the flow properties of ZOE impression paste without water and after addition of water as an accelerator for three different commercially available zinc oxide eugenol impression pastes.

\section{METHODS}

Three commercially available zinc oxide eugenol impression pastes used were - DPI (Dental Product of India), Neogenate (Septodont), IMAGE (Prime Dental Pro.Ltd). A total of 15 discs were made without accelerator and with addition of 1,2 and 3 drops of water for the three brands of the zinc oxide eugenol paste. Then the flow of each was tested. Data of flow was analysed using one way- ANOVA and post hoc test.

\section{RESULTS}

It was found that the mean flow of zinc oxide eugenol impression paste without the use of accelerator for DPI, Septodont, Image was $4.72 \pm 0.56,4.20 \pm 0.75$, and $3.50 \pm$ 0.57 respectively. The mean flow of zinc oxide eugenol impression paste with the use of one drop of accelerator for DPI, Septodont, Image was $4.98 \pm 0.3493,4.54 \pm 0.6025$, and $3.940 \pm 0.4722$ respectively. With the use of two and three drops of accelerator for DPI was $4.18 \pm 0.7259$ and $2.68 \pm 0.3701$, for Septodont was $3.880 \pm 0.6907$ and $2.32 \pm 0.2775$ and for Image flow was $3.20 \pm 0.5745$ and $1.80 \pm 0.4000$.

\section{CONCLUSIONS}

DPI had the maximum flow as compared to other brands of zinc oxide eugenol impression paste.

\section{KEY WORDS}

Zinc Oxide Eugenol, Impression Material, Flow, and Accelerator
Corresponding Author:

Dr. Uma Prabhu,

Department of Prosthodontics,

Yenepoya Dental College,

Yenepoya University, Mangalore,

Karnataka, India.

E-mail: druma241@gmail.com

DOI: $10.14260 / j e m d s / 2021 / 369$

How to Cite This Article:

Dandekeri S, D'Souza R, Prabhu UM, et al. A comparative evaluation of the rheological properties, upon addition of water, of three commercially available zinc oxide eugenol impression materials. J Evolution Med Dent Sci 2021;10(23):1788-1793, DOI: 10.14260/jemds/2021/369

Submission 27-01-2021,

Peer Review 14-04-2021,

Acceptance 21-04-2021,

Published 07-06-2021.

Copyright (c) 2021 Savitha Dandekeri et al. This is an open access article distributed under Creative Commons Attribution License [Attribution 4.0 International (CC BY 4.0)] 


\section{BACKGROUND}

Prosthesis can be fabricated accurately only when the impression made has recorded the tissues in such a way so that a precise, positive form or casts can be obtained from the recorded impression. Accurate and detailed recording of the impression is the most important factor which determines the final outcome of Prosthodontic treatment. ${ }^{1}$ Physical and chemical properties of the impression materials determine the accuracy of impression made to record the tissue details. ${ }^{2}$ The skills of the clinician and the appropriate selection and handling of suitable impression material plays a vital role in producing an accurate impression. ${ }^{3}$ Flow is that property of the material where the shape is changed whenever an external load is applied or under its own weight. ${ }^{1}$ Rheology is the study of flow characteristics. Favourable rheological properties can be obtained when materials exhibit a low viscosity. ${ }^{4}$ This is mainly due to the impression material flowing into the finer details there by replicating the exact tissue surface. Thus whenever the flow property of impression material is adequate, impression will be recorded in which there is minimum or no compression of tissues. This requirement is of great significance for the close adaptation of the denture to the tissue surfaces which in turn increases retention due to adhesion and cohesion. Various materials are used in prosthodontics to make final impression for the fabrication of prosthesis.

Impression materials with minimum flow can be used to make secondary impression so that tissue displacement is minimum, whereas there are materials which are stiffer and displace the tissues. In the maxillary and mandibular arch there are certain areas which can bear the displacing forces well. There are certain areas which cannot bear the load and tend to resorb faster underload. Thus flow property of impression materials play a vital role in the selection of impression material. The zinc oxide eugenol impression pastes are available since the 1930 's $s^{5}$ and are widely used in impression procedures in denture prosthesis. Various brands of zinc oxide eugenol impression pastes are available commercially. Even though they have general properties which are common to different brands, they differ clinically. The variations are mainly attributed to the time taken by the material to set, consistency of the material once it is set, physical properties like flow, hardness, brittleness, tackiness. Temperature and humidity in which the material sets also vary for different products. In the literature, there are studies done that record the effect of water on the setting time of zinc oxide eugenol. It was concluded that water acts as an accelerator to the setting time of ZOE impression paste.6,7,8,9,10 However, there are no studies conducted to record the effect of adding accelerators on the flow properties of zinc oxide eugenol impression pastes.

Therefore, the present study was done to compare and evaluate the flow properties of zinc oxide eugenol impression paste, commonly used as a secondary impression material without water and after addition of water as an accelerator for three different commercially available zinc oxide eugenol impression paste.

\section{METHODS}

An invitro study was conducted from March 2017 to December 2017 using three commercially available zinc oxide eugenol impression pastes namely DPI (Dental Product Of India), Neogenate (Septodont), IMAGE (Prime Dental PRO.LTD) Instruments used were 420 gms weight measure, plastic syringe, two glass plates weighing $80 \mathrm{gms}$, separating sheets from DPI, stainless steel spatula to mix the Zinc oxide eugenol impression paste, stop watch to calculate the time, glass slab on which the material was mixed and vernier callipers of $1 /$ $10^{\text {th }}$ of an mm least count. Equal lengths of the base and accelerator pastes of the three different commercially available zinc oxide eugenol materials, DPI, Neogenate and Image, were placed on a glass slab as per the manufacturer's recommendation. Flow properties of ZOE impression paste were tested in accordance with American Dental Association (ADA) specification no. 16.11 The mixed material was then placed on a cellophane sheet, which was then folded once and was made into a cone. Zinc oxide eugenol paste was then loaded in the syringe. Two plungers were then stowed into syringe. On a glass slab cellophane sheet was placed and $0.5 \mathrm{ml}$ material was injected. Glass plates weighing 80 gms and 420 gms were placed on freshly dispensed zinc oxide eugenol impression paste using a cellopane sheet. Using Vernier callipers of $1 / 10^{\text {th }}$ of an mm the diameter of the disc was noted after an application of a load for 1 minute. In the same way, five discs were made for each brand and their diameters were noted. So a total of 15 discs were obtained for the three brands of the zinc oxide eugenol paste used in this study. For the next parameter the base and accelerator pastes were taken on the glass slab in 1:1 ratio and water was added in the following proportions - 1 drop, 2 drops and 3 drops. So a total of 15 discs were obtained for the three brands of the ZOE paste used in this study with respect to the proportion of 1 drop of water and the discs were obtained in the similar manner which was explained to obtain the discs without addition of water. Similarly, the same procedure was repeated for the other proportions, that is 2 drops and 3 drops of water and a total of 5 discs were obtained for each of the brands of ZOE impression pastes used in the study with respect to each proportion. So a total of 15 discs were obtained for the proportion of 2 drops of water used as an accelerator and another 15 discs were obtained for the proportion of 3 drops of water used as an accelerator. Ethical clearance was taken from the Yenepoya Ethical Committee for the above study.

\section{Statistical Analysis}

The measurements obtained were tabulated and statistical analysis was done using one way-ANOVA test and Post Hoc test.

\section{RESULTS}

The present study was carried out to measure the rheological property of three commercially available zinc oxide eugenol impression pastes without addition of water and with addition of water as an accelerator. 
The discs were made using ZOE impression paste; diameters were recorded and were tabulated. The data obtained was subjected to statistical analysis. Mean and standard deviations for each group of data obtained was calculated. Results obtained for three commercially available zinc oxide eugenol impression paste used in the study are shown in Table 1, 2, 3 and the respective graphs plotted are shown in graph $1,2,3$.

\begin{tabular}{|c|c|c|c|c|c|c|c|}
\hline \multirow[t]{2}{*}{ Type } & \multirow[t]{2}{*}{$\mathbf{N}$} & \multirow[t]{2}{*}{ Mean } & \multirow[t]{2}{*}{ S.D. } & \multicolumn{2}{|c|}{$\begin{array}{c}\text { 95\% Confidence } \\
\text { Interval } \\
\text { for Mean }\end{array}$} & \multirow{2}{*}{$\begin{array}{c}\text { ANOVA } \\
\text { F }\end{array}$} & \multirow{2}{*}{$\begin{array}{c}P \\
\text { Value }\end{array}$} \\
\hline & & & & $\begin{array}{l}\text { Lower } \\
\text { Bound }\end{array}$ & $\begin{array}{l}\text { Upper } \\
\text { Bound }\end{array}$ & & \\
\hline $\begin{array}{l}\text { Without } \\
\text { accelerator }\end{array}$ & 5 & 4.720 & .5675 & 4.015 & 5.425 & 19.105 & $\begin{array}{c}.000 \\
\text { HS }\end{array}$ \\
\hline $\begin{array}{l}\text { With one } \\
\text { drop of } \\
\text { accelerator }\end{array}$ & 5 & 4.980 & .3493 & 4.546 & 5.414 & & \\
\hline $\begin{array}{l}\text { With tw o } \\
\text { drops of } \\
\text { accelerator }\end{array}$ & 5 & 4.180 & .7259 & 3.279 & 5.081 & & \\
\hline $\begin{array}{l}\text { With three } \\
\text { drops of } \\
\text { accelerator }\end{array}$ & 5 & 2.680 & .3701 & 2.220 & 3.140 & & \\
\hline
\end{tabular}

\section{Flow of DPI}

The mean flow recorded for DPI without the use of accelerator was $4.72 \pm 0.5675$, with the use of 1 drop was $4.98 \pm 0.3493$, with the use of 2 drops was $4.18 \pm 0.7259$ and with the use of 3 drops of accelerator was $2.68 \pm 0.3701$.

The difference in the mean obtained through one way ANOVA test was highly significant with a $P$ value of less than 0.05. On doing Post Hoc Bonferroni test, the difference in the flow without the use of accelerator and with the use of three drops of accelerator was highly significant as well as between the flow with the use of 1 drop of accelerator and three drops.

\begin{tabular}{|c|c|c|c|c|c|c|c|}
\hline \multirow[t]{2}{*}{ Type } & \multirow[t]{2}{*}{$\mathbf{N}$} & \multirow[t]{2}{*}{ Mean } & \multirow[t]{2}{*}{ S.D. } & \multicolumn{2}{|c|}{$\begin{array}{c}95 \% \text { Confidence } \\
\text { Interval } \\
\text { for Mean }\end{array}$} & \multirow[t]{2}{*}{ ANOVA F } & \multirow{2}{*}{$\begin{array}{c}P \\
\text { Value }\end{array}$} \\
\hline & & & & $\begin{array}{l}\text { Lower } \\
\text { Bound }\end{array}$ & $\begin{array}{l}\text { Upper } \\
\text { Bound }\end{array}$ & & \\
\hline $\begin{array}{l}\text { Without } \\
\text { accelerator }\end{array}$ & 5 & 4.200 & .7517 & 3.267 & 5.133 & 12.989 & $.000 \mathrm{HS}$ \\
\hline $\begin{array}{l}\text { With one drop } \\
\text { of accelerator }\end{array}$ & 5 & 4.540 & .6025 & 3.792 & 5.288 & & \\
\hline $\begin{array}{l}\text { With two } \\
\text { drops of } \\
\text { accelerator }\end{array}$ & 5 & 3.880 & .6907 & 3.022 & 4.738 & & \\
\hline $\begin{array}{l}\text { With three } \\
\text { drops of } \\
\text { accelerator }\end{array}$ & 5 & 2.320 & .2775 & 1.975 & 2.665 & & \\
\hline $\begin{array}{r}\text { Table 2. St } \\
\text { Impre }\end{array}$ & & $\begin{array}{l}\text { al Ana } \\
\text { Paste }\end{array}$ & $\begin{array}{l}\text { is }(A \\
\text { st Sa }\end{array}$ & $\begin{array}{l}\text { VA) Com } \\
\text { les unde }\end{array}$ & $\begin{array}{l}\text { aring } F l \\
\text { All the } F\end{array}$ & $\begin{array}{l}\text { ow of Sept } \\
\text { arameter. }\end{array}$ & odont \\
\hline
\end{tabular}
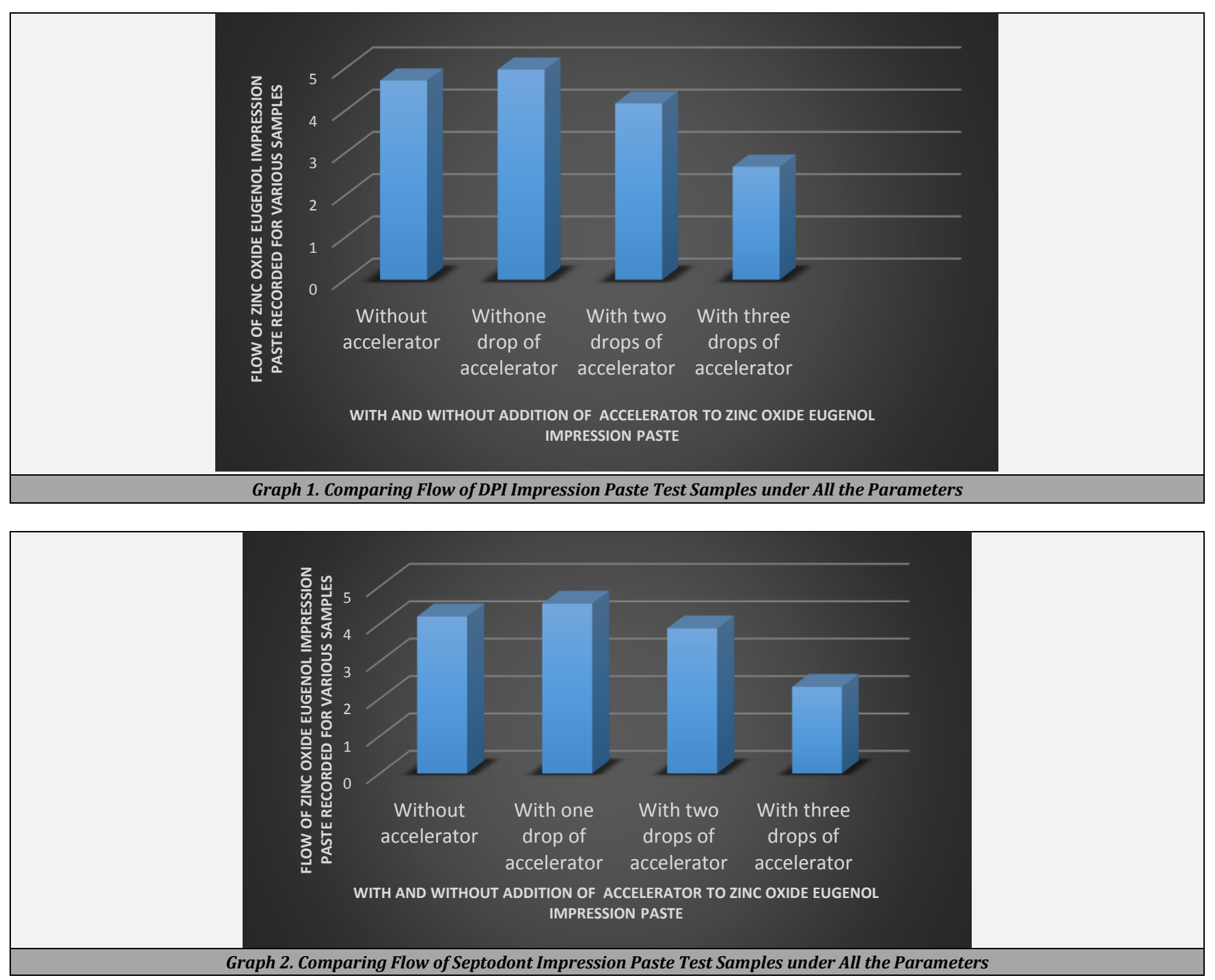


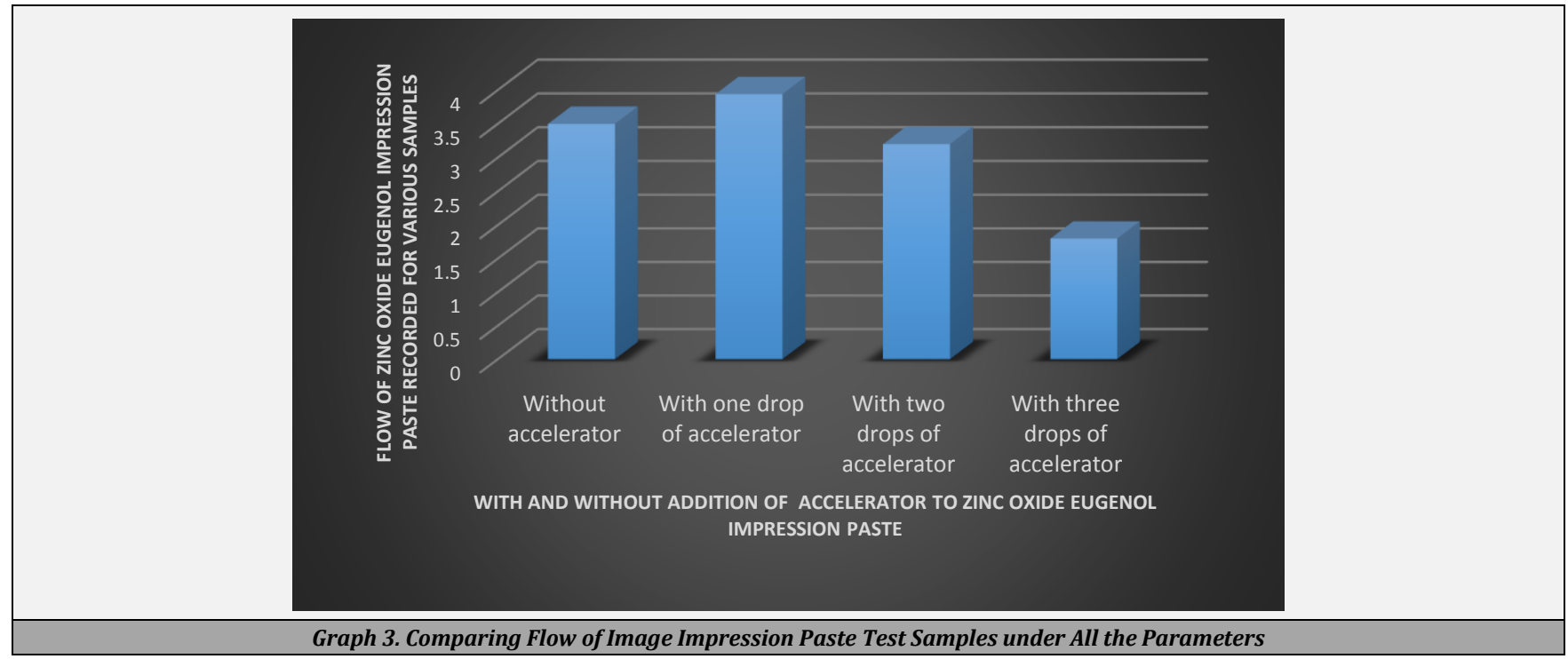

\section{Flow of Septodont}

The mean flow recorded for Septodont without the use of accelerator was $4.20 \pm 0.7517$, with the use of 1 drop of accelerator was $4.54 \pm 0.6025$, with the use of 2 drops was 3.88 \pm 0.6907 and with the use of 3 drops of accelerator was $2.32 \pm$ 0.2775 . The difference in the mean obtained through one way -ANOVA was highly significant with a P value of less than 0.05 . After conducting Post Hoc Bonferroni test, the difference in the flow without the use of accelerator and with the use of three drops of accelerator was highly significant as well as between the flow with the use of 1 drop of accelerator and three drops and also between the flow with the use of 2 drops and three drops of accelerator.

\section{Flow of IMAGE}

The mean flow recorded for Image without the use of accelerator was $3.50 \pm 0.5701$, with the use of 1 drop of accelerator was $3.94 \pm 0.4722$, with the use of 2 drops of accelerator was $3.20 \pm 0.5745$ and with the use of 3 drops of accelerator was $1.80 \pm 0.4000$.

\begin{tabular}{|c|c|c|c|c|c|c|c|}
\hline \multirow[t]{2}{*}{ Type } & \multirow[t]{2}{*}{$\mathbf{N}$} & \multirow[t]{2}{*}{ Mean } & \multirow[t]{2}{*}{ S.D. } & \multicolumn{2}{|c|}{$\begin{array}{l}\text { 95\% Confidence } \\
\text { Interval } \\
\text { for Mean }\end{array}$} & \multirow[t]{2}{*}{ ANOVA F } & \multirow[t]{2}{*}{ P Value } \\
\hline & & & & $\begin{array}{l}\text { Lower } \\
\text { Bound }\end{array}$ & $\begin{array}{l}\text { Upper } \\
\text { Bound }\end{array}$ & & \\
\hline $\begin{array}{l}\text { Without } \\
\text { accelerator }\end{array}$ & 5 & 3.500 & .5701 & 2.792 & 4.208 & 16.475 & $.000 \mathrm{HS}$ \\
\hline $\begin{array}{l}\text { With one drop } \\
\text { of accelerator }\end{array}$ & 5 & 3.940 & .4722 & 3.354 & 4.526 & & \\
\hline $\begin{array}{l}\text { With two o } \\
\text { drops of } \\
\text { accelerator }\end{array}$ & 5 & 3.200 & .5745 & 2.487 & 3.913 & & \\
\hline $\begin{array}{l}\text { With three } \\
\text { drops of } \\
\text { accelerator }\end{array}$ & 5 & 1.800 & .4000 & 1.303 & 2.297 & & \\
\hline $\begin{array}{l}\text { Table } 3.5 \\
\text { Impressio }\end{array}$ & & $\begin{array}{l}\text { istical } \\
\text { aste Te }\end{array}$ & $\begin{array}{l}\text { alysis } \\
\text { Samp }\end{array}$ & $\begin{array}{l}\text { INOVA } \\
\text { s Unde }\end{array}$ & $\begin{array}{l}\text { Imparin } \\
\text { I the } \mathrm{Pa}\end{array}$ & $\begin{array}{l}\text { Flow of In } \\
\text { ameters II }\end{array}$ & $\begin{array}{l}\text { IAGE } \\
\text { MAGE }\end{array}$ \\
\hline
\end{tabular}

The difference in the mean obtained through one way ANOVA was statistically highly significant with a p value of less than 0.05.On conducting Post Hoc Bonferroni test, the difference in the flow without the use of accelerator and with the use of three drops of accelerator was highly significant as well as between the flow with the use of 1 drop of accelerator and three drops and also between the flow with the use of 2 drops and three drops of accelerator.

\section{DISCUSSION}

An impression is defined as a negative likeness or copy in reverse of the surface of an object or an imprint of the teeth and adjacent structures for use in dentistry. ${ }^{12}$ An impression should provide retention, support and stability, preservation of the remaining structures and esthetics for the denture. ${ }^{13}$ Precise reproduction of minor details by the impression is essential for good quality of the processed denture. The adaptability between the impression material and the tissue surface depends on various properties like viscosity and surface wettability. Rheologic properties are favourable when materials exhibit a low viscosity in the beginning. ${ }^{4}$

ZOE impression paste, being mucostatic easily adapts to the soft tissues because of a water based system. Detailed reproduction of the soft tissues can be recorded without causing displacement of the soft tissues using zinc oxide eugenol impression paste. ${ }^{14}$ Most important disadvantage of ZOE impression paste is it's rigidity after setting, thereby making it difficult to record the undercuts. ${ }^{15}$ Most of the ZOE impression pastes available in the market differ in their clinical behaviour. There are variations in relation to setting time, consistency, flow and physical properties of the set material for different brands. Therefore, a comparison of the different characteristics of the impression pastes available should be carried out to aid the operator in utilizing the appropriate impression material based on the particular clinical situation. ZOE impression paste was used in this study, as it has been a commonly used impression material with satisfactorily functioning dentures. ${ }^{16,17}$ Therefore, this study compares and evaluates the flow of three brands of zinc oxide eugenol impression pastes as the first parameter as it is one of the widely used impression materials for making secondary impressions. Humidity has a considerable effect on the consistency of ZOE impression pastes. ${ }^{18,19}$ Therefore, an evaluation of the degree of change in the flow of ZOE impression paste on addition of water has been done in this 
study as the second parameter. Various organisations like American Dental Association No 16 for zinc oxide eugenol impression paste, Australian standard 18 and British standards have given specifications for measurement of flow of ZOE impression paste.

Test to determine the flow of the material was carried out by placing a given volume of mixed material on a horizontal glass slab. Load was applied which was left in position for a given amount of time. Measurement of the diameter of the resulting disc was done using Vernier callipers. ADA test used $0.5 \mathrm{ml}$ mixed material and load applied was $500 \mathrm{~g}$ for $8.5 \mathrm{~min}$. In the current in vitro study, flow of the impression paste measured was in accordance with the ADA specification. 0.5 $\mathrm{ml}$ of material was used in the form of discs, 80 gms and 420 gms of load applied for a duration of $1 \mathrm{~min}$. It was found that the mean flow of zinc oxide eugenol impression paste without the use of accelerator, after 1 min of load application for DPI was $4.72 \mathrm{~cm}$, for Septodont was $4.2 \mathrm{~cm}$ and for Image was 3.5 $\mathrm{cm}$. On statistical analysis (Post Hoc test) mean flow of the material for DPI brand at $1 \mathrm{~min}$ after load application was significantly higher than the other groups. This was in accordance with the study conducted by Katna et al. ${ }^{1}$

The mean flow of zinc oxide eugenol impression paste with the use of one drop of accelerator, after $1 \mathrm{~min}$ of load application for DPI was $4.98 \mathrm{~cm}$, for Septodont was $4.54 \mathrm{~cm}$ and for Image was $3.94 \mathrm{~cm}$. The mean flow of zinc oxide eugenol impression paste with the use of two drops of accelerator, after $1 \mathrm{~min}$ of load application for DPI was 4.18 $\mathrm{cm}$, for Septodont was $3.88 \mathrm{~cm}$ and for Image was $3.2 \mathrm{~cm}$. With respect to all the three brands, the mean flow of ZOE impression paste with the use of three drops of accelerator, after $1 \mathrm{~min}$ of load application for DPI was $2.68 \mathrm{~cm}$, for Septodont was $2.32 \mathrm{~cm}$ and for Image was $1.8 \mathrm{~cm}$. For Zinc oxide eugenol impression pastes used in this study, there was an increase in flow after addition of 1 drop of water and a marked reduction in the flow on addition of 2 drops and 3 drops of water. This reduction in flow can be attributed to the decrease in the setting time and thereby decrease in the working time with the increase in the amount of accelerator used. As the setting time of the material decreases, the viscosity of the material will increase at a faster rate, thus affecting the flow. ${ }^{20}$ With respect to all the brands of zinc oxide eugenol impression pastes used, namely DPI, Septodont and Image, DPI showed the highest flow with all the parameters tested.

\section{CONCLUSIONS}

1. DPI brand of zinc oxide eugenol impression paste had maximum flow as compared to the other brands used in the study.

2. Upon addition of one drop of accelerator it was noted that there was an increase in flow. On comparison between 1 drop and 3 drops, the flow had a significant difference while, between 1 drop and 2 drops and between 2 drops and 3 drops there was no significant difference.

3. On addition of two drops and three drops of accelerator there was a decrease in flow for all the three brands used in this study as the setting time reduced due to the use of accelerator.
Data sharing statement provided by the authors is available with the full text of this article at jemds.com.

Financial or other competing interests: None.

Disclosure forms provided by the authors are available with the full text of this article at jemds.com.

\section{REFERENCES}

[1] Katna V, Suresh S, Vivek S, et al. To study the flow property of seven commercially available zinc oxide eugenol impression material at various time intervals after mixing. J Indian Prosthodont Soc 2014;14(4):393-9.

[2] Hamid H. Commentary. Flow profile of regular and fastsetting elastomeric impression materials using a shark fin testing device. J Esthet Restor Dent 2011;23(3):177-8.

[3] Al-ahmarAO, Lynch CD, Locke M, et al. Quality of master impressions and related materials for fabrication of complete dentures in the UK. J Oral Rehab 2008;35(2):111-5.

[4] Mondon M, Ziegler C. Changes in water contact angles during the first phase of setting of dental impression materials. Int J Prosthodont 2003;16(1):49-53.

[5] Rao S, Chowdhary R, Mahoorkar S. A systematic review of impression technique for conventional complete denture. J Indian Prosthodont Soc 2010;10(2):105-11.

[6] Wilson AD, Mesley RJ. Zinc oxide-eugenol cements. 3. Infrared spectroscopic studies. J Dent Res 1972;51(6):1581-8.

[7] Wilson AD, Clinton DJ, Miller RP. Zinc oxide-eugenol cements. IV. Microstructure and hydrolysis. J Dent Res 1973;52(2):253-60.

[8] Copeland HI, Brauer GM, Sweeney WT, et al. Setting reaction of zinc oxide and eugenol. J Res Nat Bur Stds 1955;55(3):133-8.

[9] Braden M, Clarke RL. Dielectric properties of zinc oxideeugenol type cements. J Dent Res 1974;53(5):1263-67.

[10] Smith DC. The setting of zinc oxide eugenol mixture. Brit Dent J 1958;105:313-21.

[11] Yrastorza JA. Council adopts changes in American Dental Association Specification No. 16 for impression pastezinc oxide-eugenol type. Council on dental research. J Am Dent Assoc 1963;67:927.

[12] Driscol CF, Freilich MA, Guckes AD, et al. The glossary of prosthodontic terms: ninth edition. J Prosthet Dent 2017;117(5S):e1-105.

[13] Zarb G, Hobkirk JA, Eckert SE, et al. Prosthodontic treatment for edentulous patients. $13^{\text {th }}$ edn. St. Louis: Elsevier Mosby 2013:161-17.

[14] Amjad H, Khan J, Bangash MFK. Impression techniques and materials used for fabrication of complete denture. A survey. Pak Oral Dent J 2014;34(1):170-3.

[15] Chopra S, Gupta NK, Tandan A, et al. Comparative evaluation of pressure generated on a simulated maxillary oral analog by impression materials in custom trays of different spacer designs: an in vitro study. Contemp Clin Dent 2016;7(1):55-60.

[16] Woelfel JB. Contour variations in impressions of one edentulous patient. The Journal of Prosthetic Dentistry 1962;12(2):229-54.

[17] Rupal S, Sanjay B, Prakash K, et al. Complete denture impression techniques practiced by private dental 
practitioners: a survey. IOSR J Dent Med Sci 2015;14(6):111.

[18] Clark RJ, Phillips RW. Flow studies of certain dental impression materials. J Prosthet Dent 1957;7(2):259-66.

[19] Craig RG, Powers JM. Restorative dental materials. $11^{\text {th }}$ edn. St. Louis: Mosby 2002:580.
[20] Chandak AH, Deshmukh SP, Radke UM, et al. An in vitro study to evaluate and compare the flow property of different commercially available zinc oxide eugenol impression materials. Contemp Clin Dent 2018;9(Suppl 1):137-41. 